\title{
Ecological and economic valuation of the Potengi estuary mangrove wetlands (NE, Brazil) using ancillary spatial data
}

\author{
Flavo E. S. Souza • Carlos Augusto Ramos e Silva
}

Received: 1 April 2010 /Revised: 5 August 2010 / Accepted: 5 October 2010 /Published online: 20 October 2010

(C) The Author(s) 2010. This article is published with open access at Springerlink.com

\begin{abstract}
This study aimed at the ecological-economic valuation of the Potengi estuary mangrove wetlands, based on the integration of spatial data (mangrove forest coverage map, Nautical Chart, Environmental Sensitivity Chart) with data from literature on the biogeochemistry of nitrogen $(\mathrm{N})$, phosphorus (P), and heavy metals in the mangrove estuary wetland Potengi) and field verification data (topographic profile of mangrove forest, GPS routes obtained in the field in the touristy sightseeing areas and plots of mariculture). The ecological and economic valuation of the services performed by the Potengi estuary mangrove wetlands, mainly as biogeochemical barrier for the transport of $\mathrm{P}, \mathrm{N}$ and heavy metals in tropical coastal areas, were obtained just as if the retention of those elements was necessary by Wastewater Treatment Plants (WTP) with Stabilization Ponds, typical in the estuary, and Zeolitic plant, respectively. Closer to real scenarios were observed for obtaining the values of these ecological services, such as the release of the $\mathrm{P}, \mathrm{N}$ and heavy metals in domestic and industrial sewage in
\end{abstract}

\section{F. E. S. Souza}

Department of History and Geography,

Center of Higher Education Seridó, UFRN,

Joaquim Gregorio Street,

Caicó, RN 59300-000, Brazil

\section{A. Ramos e Silva}

Department of Oceanography and Limnology (Laboratory of Environmental Biogeochemistry), Federal University of Rio Grande do Norte (Universidade Federal do Rio Grande do Norte), Natal, RN CEP 59075-970, Brazil

Present Address:

C. A. Ramos e Silva $(\square)$

Department of Marine Biology, Fluminense Federal University

(Universidade Federal Fluminense),

Niterói, RJ PO Box 100644, CEP: 24001-970 Brazil

e-mail: caugusto_99@yahoo.com the estuary, the capability of dilution and the influence of the tides in the estuary. The tourism potential of the Potengi estuary mangrove wetlands were assessed according to the current forms of use, and potential of aquaculture through the main types of farming in mangrove areas. For these ecological services, considerable values were obtained of about USS15,500/ha, such as costs of implementation and construction of sewage treatment plants, as well as costs of sewage treatment plants. Nearly US\$ 12.500 / ha amount each year from tourism and aquaculture income, demonstrating the economic viability of the Potengi estuary mangrove wetlands conservation.

Keywords Valuation · Estuary · Mangroves · Spatial Data . Conservation

\section{Introduction}

The ecological-economic valuation of mangrove wetlands is one of the main aid mechanisms for management plans and conservation of this ecosystem (Grasso et al. 1997). Yet, it is reflected in the managers' increasing awareness of the enormous contribution of natural ecosystems to human welfare (Barbier 1989; Barbier et al. 2008; Luzadis et al. 2010).

Thus, through analysis of cost-benefit of the different forms of use of mangrove wetlands, susceptible transformations and even their destruction can be avoided at the extent to which the fishing communities and institutions involved in relevant decision making can be oriented, making them aware of the ecological and economic value of ecosystems (D'Croz and Kwiecinski 1980).

The ecological and economic valuation of the mangroves is made based on the products that are derived directly and indirectly from this ecosystem, and on the services, which are the ecological functions performed by the system. 
(Barbier 1989; Grasso et al. 1997; Barbier et al. 2008). Recently, a greater emphasis has been given to the mangrove environmental services, such as protecting the coastal area against storms, and its role as biogeochemical barrier to the transit of heavy metals in tropical aereas (Ramos e Silva et al. 1990, 1991, 2006, 2007), and also, in the biological filtration of the loads of nitrogen $(\mathrm{N})$ and phosphorus $(\mathrm{P})$ arising from domestic effluents and agribusiness (Robertson and Phillips 1995), which can propiciate the valuation of these environmental services.

In recent decades the mangrove estuary Potengi has suffered severe environmental degradation. One of the main causes of this degradation is the urban sprawl of the cities of Natal, São Gonçalo do Amarante and Macaíba, increasing the release of industrial wastewater and domestic "in nature" sewage in the estuary. The expansion of shrimp farms and the use of these areas for construction of stabilization ponds for domestic sewage are also other causes of degradation of The Potengy mangrove estuary. In 1997 these practices had already increased the destruction of 436.60 ha of mangrove forest of the existing total of 1488 ha across the Potengi estuary, which corresponded to the destruction of about $30 \%$ of mangrove areas.

The urban population of the cities, estimated by the year 2000 census, located on the banks of the Potengi estuary is of about 758,156 inhabitants (IBGE 2000). The urban area is served by only $25 \%$ of the sewer system, and $60 \%$ of the sewage are released without any treatment in the estuary (CAERN 1995). An average of $15,000 \mathrm{~m}^{3}$ of sewage are launched in the Potengi estuary per day (SEPLAN / RN 1992). Assuming a population growth around $1.8 \%$ per year (IBGE 2000), the estimated amount of sewage released in 2000 reaches about $25,000 \mathrm{~m}^{3} /$ day. The chemical characteristics of raw domestic sewage indicate a concentration of total phosphorus of $14 \mathrm{mg} / \mathrm{L}$ (total organic P - $4 \mathrm{mg} / \mathrm{L}$ and total inorganic P-10 mg / L) and total nitrogen of $50 \mathrm{mg} / \mathrm{L}$ (total organic $\mathrm{N}-20 \mathrm{mg} / \mathrm{L}$ and total inorganic $\mathrm{N}-30 \mathrm{mg} / \mathrm{L}$ ) (Sperling 1996).

The portuary and industrial activity is well developed with an emphasis on the textile and tannery. Ramos e Silva et al. (2001) and Ramos e Silva et al. (2003) showed that the entry of heavy metals $(\mathrm{Fe}, \mathrm{Zn}, \mathrm{Cu}, \mathrm{Cr}, \mathrm{Pb}, \mathrm{Cd}, \mathrm{Ni}$ and $\mathrm{Ag}$ ) in the Potengi estuary has become a public health risk, when five sampling stations showed concentrations of $\mathrm{Cu}$, $\mathrm{Zn}$ and $\mathrm{Pb}$ which are above the standard permitted.

Based on a scenario of environmental degradation of the Potengi estuary, this study aimed the valuation of the ecological services provided by mangrove forest in this estuary, based on the integration of spatial data (land cover vegetation and land user) and (data report) data that were published in studies on the Potengi estuary mangrove wetlands. The services or the ecological functions valued were the biogeochemical barrier roles in the transport of $\mathrm{P}$,
$\mathrm{N}$ and heavy metals in tropical coastal areas (Ramos e Silva et al. 1990, 2006, 2007).

Due to the ecological services performed by the mangroves of constant maintenance of the estuarine water quality, turning it possible its use by the tourism and the aquaculture, the potential use of the mangrove wetlands for such activities was also valued. Spatial data such as routes used for tourism (scenic, landscape, recreation, environmental education, and research), and sites used by family aquaculture (cultivation of oysters, mussels, algae on rafts or fixed structures, and fish and shrimps in floating cages) were used to estimate values of tourism uses and aquaculture income from the areas of mangroves.

\section{Study area}

The Potengi estuary is located on the east coast of Rio Grande do Norte in northeastern Brazil, between the geographical coordinates of latitude $5^{\circ} 43^{\prime} \mathrm{S}$ to $5^{\circ} 53^{\prime} \mathrm{S}$ and $35^{\circ} 09^{\prime} \mathrm{W}$ to $35^{\circ}$ $21^{\prime} \mathrm{W}$, with about $20 \mathrm{~km}$ length of its estuarine zone bordered by mangrove forest, going through the cities of Natal, São Gonçalo do Amarante and Macaíba (Fig. 1).

The climate in the region is hot and humid, being determined by a dry season in summer and rainy in winter, reaching the highest levels of rainfall recorded in Rio Grande do Norte, varying from 1,300 to about $2,000 \mathrm{~mm} /$ year. The highest average rainfall occurs between April and June, and the lowest from October to December. The average annual temperature is $26.8^{\circ} \mathrm{C}$. The average annual minimum temperature is $24.3^{\circ} \mathrm{C}$. The relative humidity, generally stable, is about $80 \%$. The coldest months correspond to those of the rainy season and the warmer months to those of the dry the season (UFRN 2004).

The mangrove forest covers an area of 1488 ha in the Potengi estuary being composed of three species of trees: the Rhizophora mangle (red mangrove or cobbler mangrove) with a great predominance $(62 \%)$ close to the river mouth and the margins, Laguncularia racemosa (white mangrove or tame mangrove) of about $21 \%$ more towards the insides of the margins, and Avicennia germinans (black mangrove) which are in the most inland of the estuary, together with smaller and scattered individuals of $R$. Mangle and $L$. Racemosa, with about 17\% (SEPLAN / RN 1986; Souza 1999). In the Potengi estuary, in areas with greater tidal influence, there are densities of 3,200 trees / ha with individuals as high as $10 \mathrm{~m}$ high (Ramos e Silva et al. 2006).

\section{Materials and methods}

According to Ramos e Silva et al. (2007) (Fig. 2), the role of mangrove forests as a reservoir of $\mathrm{P}$ and $\mathrm{N}$ in the 


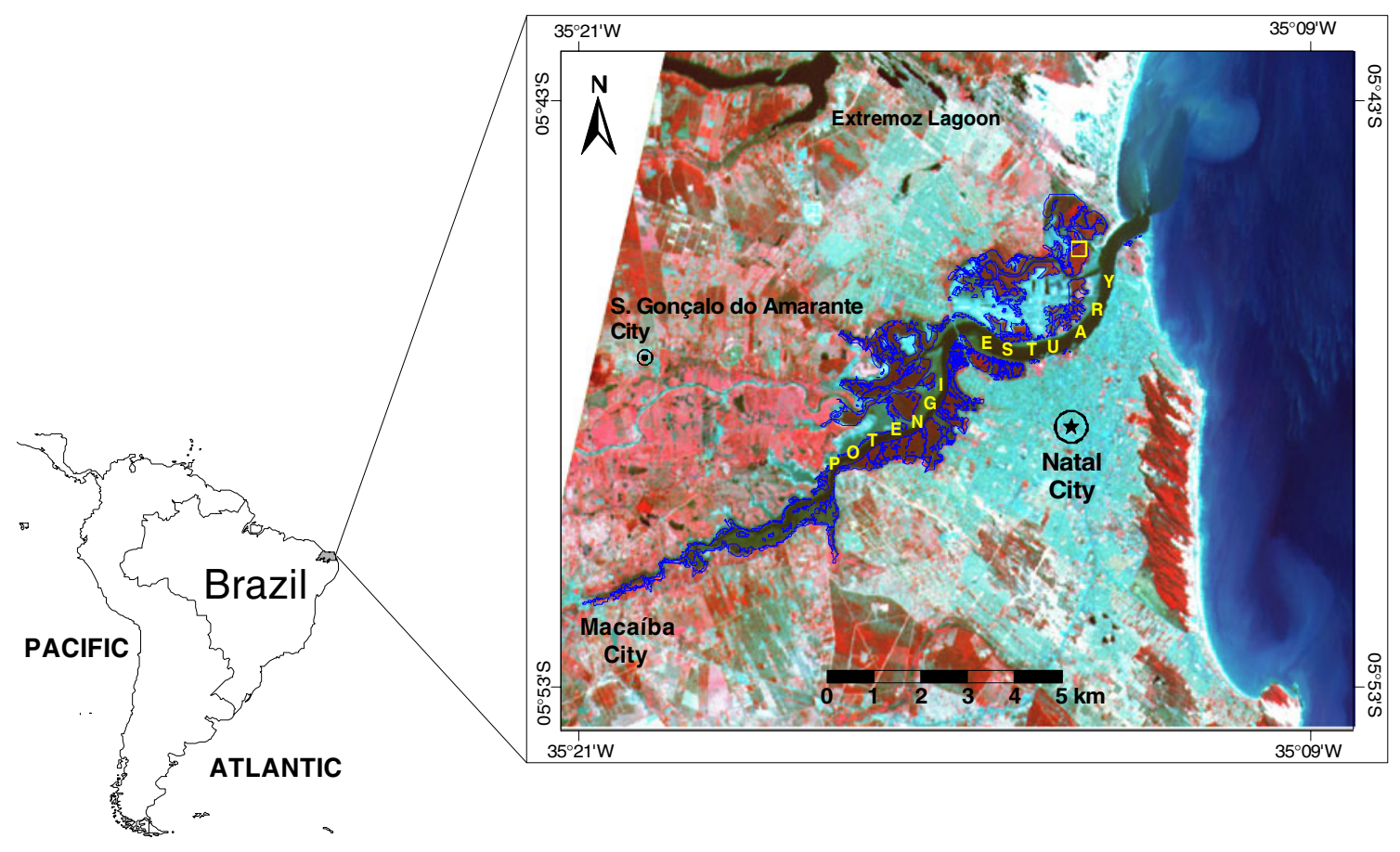

Fig. 1 Potengi Estuary with location of mangrove areas (areas with blue edges) and the mangrove forest transect used to study the dynamics of $\mathrm{P}$, $\mathrm{N}$ and heavy metals (yellow square). 321 RGB color composite of SPOT / HRV scene 731/362, 07.05.1994

sediments of Potengi estuary mangrove wetlands in a plot dominated by R. Mangle, has estimated loads of the $309 \mathrm{~kg} /$ ha of $\mathrm{P}$ and $4,619 \mathrm{~kg} / \mathrm{ha}$ of $\mathrm{N}$. The biological compartment (estimed in 107,460 kg / ha), from this plot forest biomass per hectare, with stocks of $145 \mathrm{~kg} /$ ha P and $215 \mathrm{~kg} /$ ha of $\mathrm{N}$, and a renewal rate (turnover rate), given by the release of cargo from litter in relation to the loads stored in the biomass by trees of $12.5 \mathrm{~kg} / \mathrm{ha} /$ year for P and $32.6 \mathrm{~kg} / \mathrm{ha} /$ year for $\mathrm{N}$, corresponding, for example, to a renewal of the stocks on average every 12 years and 7 years, respectively (Ramos e Silva et al. 2007).

The loads of $\mathrm{P}$ and $\mathrm{N}$ stored in the sediments $\left(E_{s}\right)$ and biomass $\left(E_{b}\right)$ in the mangrove trees from Potengi estuary were estimated using the concentrations based on data from Ramos e Silva et al. (2007) (Fig. 2), and multiplied by the area in hectares where part of forest is dominated by $R$. Mangle (about 920 ha) similar to the vegetation of that area of the transect (plot), according to the estuary Potengi mangrove coverage map (Fig. 1) (SEPLAN / RN 1986; Souza 1999).

\section{Valuation of retention services of loads of phosphorus $(\mathrm{P})$, nitrogen $(\mathrm{N})$ and heavy metals}

The valuation of the role of loads of nitrogen $(\mathrm{N})$, phosphorus (P) and heavy metals retention in the mangrove forest of the Potengi estuary, both in the sediments as well as in the trees (biomass), and through the renewal rate (turnover rate) of these elements in the ecosystem, had its costs estimated as if they had been retained for Wastewater Treatment Plant (WTP), similar to those situated on the banks of the Potengi estuary.

Considering in this case some conditions to estimate the valuation of the capacity of estuarine water purification by the mangrove forest were assumed:

a) that the estuary is a closed system to the exchange of $\mathrm{P}$ and $\mathrm{N}$ with the ocean;

b) the loads of $\mathrm{N}$ and $\mathrm{P}$ from sewage available to mangroves refer to only those on tide heights that flood the mangrove forest, given the fact that only the influence of the tide can provide nutrients to the mangrove forest (Ramos e Silva 1996);

c) that the tides that flood the forest are semi-diurnal, given by their daily peaks where each peak occurs at intervals of $06 \mathrm{~h}$. It is also considered that the tidal heights that flood the forest (from $0.4 \mathrm{~m}$ ) were obtained from topographic profile in the study area (Fig. 3), where the level reference was the neap (0.0), and its incidence given by the average annual frequency according to the tide boards to the Port of Natal in 1995, 1996 and 1997 (DHN. Marinha do Brasil 2004);

d) and that the loads are evenly diluted in the volume of water of the estuary and entirely retained by the mangrove forest, having the volume at the tide height of $(0.0 \mathrm{~m})$ at the Potengi estuary of $18,607,200 \mathrm{~m}^{3}$ (CAERN 1995). 


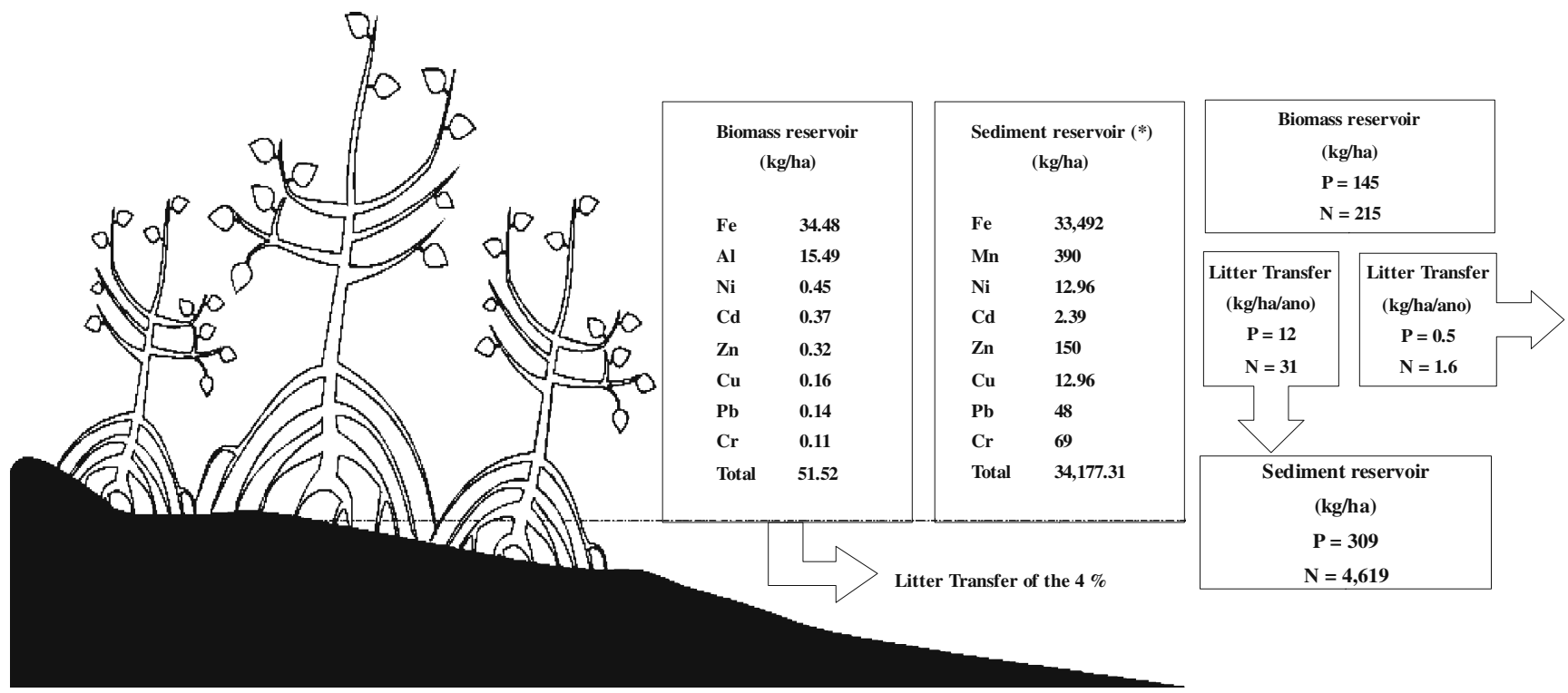

Fig. 2 Dynamics of P, N and heavy metals in the Potengi estuarine mangrove forest. $\left({ }^{*}\right)$ The stocks of heavy metals in sediments relate to the mangroves of the Baía de Sepetiba / RJ (Mod. Ramos e Silva et al. 2006)

Aiming to obtain a closer to scenario described, the annual load of $\mathrm{P}$ and $\mathrm{N}$ (Load kg/year) was according to the following formula: $\operatorname{Load}_{\mathrm{kg} / \text { year }}=\left[\left(C^{*} Q_{\text {med }} / 4\right) / 1000\right]^{*}$ $\sum f_{t}$, where $(C)$ is the typical concentration in domestic sewage in $\mathrm{mg} / \mathrm{L}$ of $\mathrm{P}$ and $\mathrm{N}$, $\left(Q_{\text {med }}\right)$ corresponds to an average daily flow of sewage discharged into the estuary, in this case, 25,000 m3/day, which for approximation purposes corresponds to $1 / 4$ of the day due to the semi-diurnal tides in $06 \mathrm{~h}$, and $\left(\Sigma f_{t}\right)$ is the sum of average annual frequency of each tidal height (meters) over $0.4 \mathrm{~m}$ (Fig. 3), resulting in total of the annual load in $\mathrm{kg}$ of $\mathrm{N}$ and $\mathrm{P}$ available to mangrove wetlands. Because of unit conversions from $\mathrm{mg}$ to $\mathrm{kg}$ and liters to $\mathrm{m}^{3}$, the result was divided by 1000 . The total concentrations of $\mathrm{N}$ and $\mathrm{P}$ in $\mathrm{mg} / \mathrm{L}$ in the typical composition of domestic sewage was $14 \mathrm{mg} / \mathrm{L}$ for P and $50 \mathrm{mg} / \mathrm{L}$ for N (CAERN 1995; Sperling 1996).
As the cost of deploying a WTP is based on the number of inhabitants, then from the average daily flow $\left(Q_{\text {med }}\right)$ it was possible to determine the population corresponding to the flow of sewage discharged into the Potengi estuary, according to Sperling (1996), $P=\left(Q_{\text {med }}{ }^{*} 1000\right) /\left(Q_{i}{ }^{*} C_{i}\right)$, where $(P)$ is the number of inhabitants, $\left(Q_{i}\right)$ is the rate of per capita water consumption of $220 \mathrm{l} /$ inhabitants, and $\left(C_{i}\right)$ the rate of return of $80 \%$ for water in the sewage disposal system. As the average daily flow of domestic sewage $\left(Q_{\text {med }}\right)$ launched in the Potengi estuary was $25,000 \mathrm{~m}^{3} /$ day, this corresponded to the discharge of sewage from a population of about 140,000 inhabitants.

The costs of WTP for the primary treatment (railing, sand pit, primary sedimentation tank, aeration tank) for later disposal in waste stabilization ponds, according to the ABES (1984), would be US\$21.00/inhabitant for primary treat-
Fig. 3 a Topographic profile of the transect of Potengi estuary mangrove forest used to study the dynamics of $\mathrm{N}$ and $\mathrm{P}$ and heavy metals (Ramos e Silva et al. 2006, 2007). b Frequencies of tidal heights $(f)$ flooding the mangrove forest $(H t)$ per year

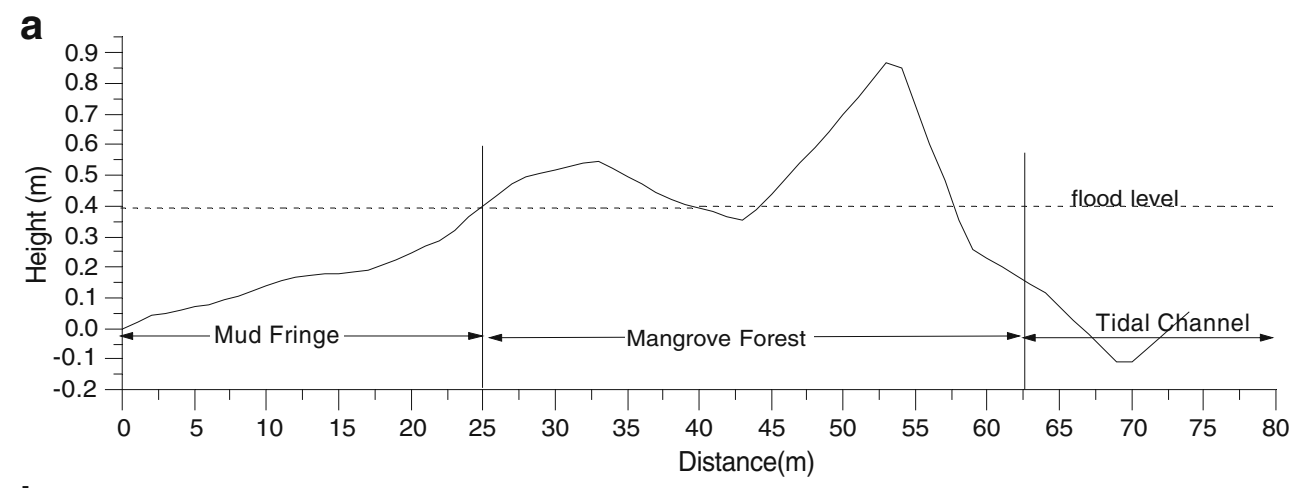

b

\begin{tabular}{c|ccccccccccccccccccc}
\hline $\begin{array}{c}\boldsymbol{H}_{\boldsymbol{t}} \\
(\boldsymbol{m})\end{array}$ & 0.4 & 0.5 & 0.6 & 0.7 & 0.8 & 0.9 & 1.0 & 1.4 & 1.5 & 1.6 & 1.7 & 1.8 & 1.9 & 2.0 & 2.1 & 2.2 & 2.3 & 2.4 & Total \\
\hline $\boldsymbol{f}$ & 69 & 77 & 75 & 63 & 32 & 09 & 01 & 05 & 16 & 48 & 94 & 114 & 123 & 111 & 80 & 39 & 14 & 03 & 973 \\
\hline
\end{tabular}


ment, and US\$ 14.00/inhabitant for the construction of stabilization ponds. The whole system would be US\$ 35.00/ inhabitant (ABES 1984). In the annual operational costs $40 \%$ of the workforce would be included, being one operator for every 10,000 inhabitants, with a salary of US\$ $300.00 /$ month, and the remaining cost of inputs, system maintenance and electricity (ABES 1984).

Considering the stabilization ponds of a WTP have the efficiency of removing $30 \%$ of the $\mathrm{P}$ load and $40 \%$ of the $\mathrm{N}$ (Hammer 1979), it was also taken into consideration in the valuation of $\mathrm{N}$ and $\mathrm{P}$ the costs fell upon the treatment efficiency of a WTP which opts for a partial treatment, increasing the treatment time by $60 \%$ reflecting on the costs of treatment for total removal of the loads of $\mathrm{P}$ and $\mathrm{N}$.

Thus, the total costs of construction of the WTP $\left(C_{b}\right)$, corresponded to: $C_{b}=\left(140,000\right.$ inhab. ${ }^{*} U S \$ 35.00 /$ Inhab. $)$, and the cost of handling the loads of $\mathrm{N}$ and $\mathrm{P}\left(C_{t}\right)$, in this case given by, $C_{t}=t^{*} 1.6^{*}[1.4 *$ (14 operator * US\$ 300 salary / month * 12 month)], where $(t)$ is the treatment time multiplied by the product of the factor of the increase of treatment time by $60 \%$ (1.6) due to the treatment efficiency of $40 \%$ of the loads of $\mathrm{P}$ and $\mathrm{N}$ in WTP with stabilization ponds, and still having the product of 1.4 multiplied by the constant value referring to added to the cost of inputs $(40 \%$ of the labor work), by the product of the number of operators required for a population of 140,000 inhabitants with a monthly salary of these operators for one year.

The WTP's treatment time was equivalent to the necessary time that loads of $\mathrm{P}$ and $\mathrm{N}$ released from sewage in the Potengi estuary would take to achieve the stock of $\mathrm{P}$ and $\mathrm{N}$ present in the sediments of the mangrove forest and the trees. The annual treatment time was given regarding the removal of the loads of litter, or the capacity for renewal "turnover rate" of these elements in the ecosystem (Ramos e Silva et al. 2007).

The treatment time in years $(t)$ estimated for the loads of $\mathrm{N}$ and $\mathrm{P}$ stored in sediments of mangrove forest $\left(E_{s}\right)$ and in the mangrove trees $\left(E_{b}\right)$, or biomass, was given by, $t=$ $\left(E_{s}+E_{b}\right) /$ Load $_{k g / \text { year }}$. Treatment time in years $(t)$ of the loads stored in the trees and in the sediments was used to estimate the cost of treating $\left(C_{t}\right)$ the loads of $\mathrm{P}$ and $\mathrm{N}$.

The annual costs according to the renewal rate "turnover rate" of $\mathrm{P}$ and $\mathrm{N}$ from the mangrove forest, which according to Ramos and Silva et al. (2007), the stocks in the biomass are renewed every 12 years and 7 years for $\mathrm{P}$ and $\mathrm{N}$, respectively, were obtained by the value of the annual storage $\left(T_{r}\right)$ in the forest from the trees given by the ratio of stocks of $\mathrm{P}$ and $\mathrm{N}$ in trees $\left(E_{b}\right)$ compared to sediments $\left(E_{s}\right)$, resulting in treatment costs regarding storage by biomass, thus multiplied by the cost of treatment $\left(C_{t}\right)$, given by the formula, $T_{r}=\left[\left(E_{b} / E_{s}\right) * C_{t}\right] / t_{b}$, where $\left(t_{b}\right)$ corresponded to 12 years for $\mathrm{P}$, and 7 years for $\mathrm{N}$.

For comparison with other works, the cost of constructing a WTP $\left(C_{b}\right)$ and the cost of treatment $\left(C_{t}\right)$ of the loads of P and $\mathrm{N}$ were added and divided by the area of mangrove forest $\left(A_{m}\right)$ in hectares, given by, $V_{\$}=\left[\left(C_{b}+C_{t}\right) / A_{m}\right)$, and the annual cost of treatment of the loads of $\mathrm{P}$ and $\mathrm{N}$ were taken as the renewal rate (turnover rate) ( $\mathrm{Tr}$ ), and also divided by the area of mangrove in hectares, given by, $V_{a \$}=\left(T_{r}\right) / A_{m}$.

The capacity of retention of heavy metals by the Potengi estuary's mangrove forest was valued similarly to the above, being the retaining service (filter) of heavy metals Compared to an industrial WTP. The cost of heavy metals' treatment is complete removal by the zeolitic Plant, are around US\$ $0.44 / \mathrm{kg}$ of species of heavy metals. Before the advent of this technology the costs were estimated at US\$ 1$2.00 / \mathrm{kg}$ to US\$ 300-400.00/kg (Biomin 1999).

Similar to the treatment of domestic sewage, the zeolitic plant needs other processing steps (grill, sand pit, primary sedimentation tank, aeration tank) until there is contact of the effluent in the zeolite filters (Biomin 1999). In this way, the costs pertaining to the construction of zeolitic Plant aggregated the construction costs $\left(C_{b}\right)$ and the cost of treatment $\left(C_{t}\right)$ of a conventional WTP by approximately $10 \%$, considering an industrial complex that produces a sewage flow from $2,500 \mathrm{~m}^{3} /$ day, which means $10 \%$ of the flow of domestic sewage released in the Potengi estuary $\left(25,000 \mathrm{~m}^{3} /\right.$ day $)$, which is a standard interface for discarding waste in industrial areas (Hammer 1979; Imhoff 1996).

The loads of heavy metals stored in sediments $\left(E_{s}\right)$ and in the forest trees $\left(E_{b}\right)$ were extrapolated to the mangrove forest areas of the Potengi estuary, estimating hypothetical stocks of heavy metals in compartments of the forest, being the service of valuation of the retention of heavy metals $\left(V_{\$ h m}\right)$ equivalent to: $\left(V_{\$ h m}\right)=\left(\left[\left(C_{b}+C_{t}\right) * 0.1\right]+\right.$ $\left.\left[\left(E_{S}+E_{b}\right) * U S \$ 0.44\right]\right)$ which corresponds to $10 \%$ of the value of construction and treatment of a conventional WTP, also added to the costs of removal of US\$ $0.44 / \mathrm{kg}$ for species of heavy metals stocked in the mangrove sediments and trees.

According to Ramos and Silva et al. (2006), the stocked loads for kinds of heavy metals in mangrove trees $\left(E_{b}\right)$ of the Potengi estuary (Fig. 2) corresponded to a total of $51.52 \mathrm{~kg} / \mathrm{ha}$. Regarding the dynamics of metals in the biota, it appears that in the tissues of evergreen trees are the highest concentrations of heavy metals like $\mathrm{Fe}, \mathrm{Zn}, \mathrm{Pb}, \mathrm{Cd}$, $\mathrm{Cu}, \mathrm{Cr}, \mathrm{Ni}$, and $\mathrm{Al}(99.5 \%, 96.2 \%, 97.6 \%, 100.0 \%, 98.3 \%$, $99.2 \%, 97.3 \%$ and $98.2 \%$, respectively), whereas in deciduous tissues (leaves) are the lowest concentrations of 4\% (Ramos e Silva et al. 2006).

The dynamics of metals in the biota of the Potengi estuary have the similar scenario found in the mangrove wetlands of Sepetiba Bay / RJ, southeastern Brazil, according to Ramos e Silva et al. (2006), showing that the mangrove forest is an important biogeochemical barrier to heavy metals.

In the mangrove wetlands of Sepetiba Bay / RJ, the charges stored in the sediments of the forest make up the 
largest reservoir of heavy metals in the ecosystem, being approximately $99 \%$ compared to the biota (Ramos e Silva et al. 1990). Because of the similarity of these scenarios and the lack of data on concentrations of heavy metals in sediments of the Potengi estuary mangroves, the loads stored in the sediments $\left(E_{s}\right)$ of Sepetiba Bay / RJ (Fig. 2) were used in the valuation of ecological service of heavy metal removal by the Potengi estuary's mangrove ecosystem.

\section{Valuation of the potential for tourism and aquaculture}

The capabilities resulting from the constant maintenance of water quality by the mangroves were also valued, such as aquaculture and tourism. The valuation of the tourist potential offered by the Potengi estuary mangrove was achieved by the tourism use practiced in the environment where the mangrove forest is inserted (Van Der Knaap 1999). Tourist services $\left(S_{t}\right)$ were divided into classes according to the direct and indirect use of the scenario of mangrove forest (Barbier 1989). The indirect uses are the environment's impression and contemplation. The direct uses are environmental education, recreation and researches. In indirect uses the share corresponding to valuation of tourism services of mangroves was $1 / 3$ (one third), understood as cost of travel opportunity (Grasso et al. 1997). In the direct uses, the values of tourism services were plain.

The valuation was based on the number of users in the years of increased movement of tourists, obtained from the providers that make the crossing of the estuary Potengi 's records in the municipal transport service bureau (STTU / NATAL 1999), as well as from operators that offer ecotourism, educational and cultural services related to mangroves (Capitania das Artes / NATAL 1999). Also, tours held in the Gamboa Ceará-Mirim estuary (Extremoz / $\mathrm{RN}$ ), conducted by fishermen in canoes, were considered as an alternative exploitation means to the estuary Potengi.

Each pathway of all tourism services provided was performed, and the route mapped out in the field by GPS (Garmin 1998). The route was uploaded in the program CartaLinx v. 1.1 as vector file in order to compare with the possible scope of mangrove forest which serves as a backdrop in such transfers identified in the field by map. The data in vector format allowed measuring the perimeters of forest viewed by users of each tourism service (Clarklabs 1999; Van Der Knaap 1999).

The total annual value of each tourist service was distributed by the perimeter of the forest offered as a scenario, given by $S_{t}=\left(U_{t}^{*} P_{t}^{*} V_{t}\right) / P r_{t}$, where $\left(S_{t}\right)$ is the annual value per kilometer of mangrove offered as a scenario by the tourism bureau, $\left(U_{t}\right)$, the number of users per tour $\left(P_{t}\right)$, price paid per user, $\left(V_{t}\right)$, number of trips throughout the year, and $\left(\operatorname{Pr}_{t}\right)$, the perimeter of mangroves at kilometer offered as backdrop by the service.

The tourism potential value $\left(V_{t}\right)$ estimated for all the tourism services $\left(S_{t}\right)$ by the perimeter of mangrove forest in kilometer $\left(P r_{t}\right)$ used as a backdrop, was given by, $V_{t}=\Sigma S_{t}$ ' $\Sigma P r_{t}$, resulting in the potential value of tourism use per kilometer for comparison with other works.

The valuation of the potential for aquaculture provided by the Potengi estuary mangrove's environment was estimated by identifying areas suitable for growing of oysters, mussels, algae (rafts or fixed structures), fish and shrimp (floating cages) by family cultivation. The Nautical Chart of the Port of Natal / RN (DHN. Marinha do Brasil 1973) was used to select areas that are situated between $01 \mathrm{~m}$ to $05 \mathrm{~m}$ depth, excluding the areas that were close to boats traffic. The Potengy Estuary's Environmental Sensitivity Charts (MARPETRO 2002) was used to exclude areas of mariculture subject to risks of oil spills and tankers traffic, selecting the areas that stood near the existing areas of mariculture already in the estuary borders.

This nautical and environmental sensitivity charts were also scanned in the program CartaLinx v. 1.1 (ClarkLabs 1999) to outline the water depths of between $01 \mathrm{~m}$ to $05 \mathrm{~m}$ near the existing cultivations, as well as for exclusion of those areas close to channels that serve the shipping and tanker traffic.

The areas identified for mariculture were measured in hectares, and valued according to: $V_{c}=P_{c} *\left(A_{c} / 5\right) * \$_{c}$, where the annual productivity of each crop $\left(P_{c}\right)$ in $\mathrm{kg} / \mathrm{ha} /$ year was extrapolated to the area of cultivation $\left(A_{c}\right)$ divided for each type of cultivation (algae, oysters, mussels, fish and shrimp) and multiplied by the local market prices $\left(\$_{c}\right)$ in US\$, estimating the value $\left(V_{c}\right)$ by type of organism cultivated in US\$ / year.

The estimated value of each form of culture $\left(V_{c}\right)$ in US\$ / year was added together and divided by the area of mangrove forest in hectares $\left(A_{m}\right)$, resulting in the potential value of mangroves use for aquaculture $\left(V_{a}\right)$ at US $\$$ ha/year for comparison with other works, given by: $V_{a}=\Sigma V_{d} / A_{m}$.

\section{Results and discussion}

The estimated loads stored in the sediments $\left(E_{S}\right)$ and in the trees $\left(E_{b}\right)$ for the forest area dominated for the R. Mangle, equivalent to about 920 ha, $62 \%$ of mangrove wetland area around the Potengi estuary (1488 ha), summed up $418,400 \mathrm{~kg}$ of $\mathrm{P}$ and $4,447,800$ of $\mathrm{N}$.

The loads of $\mathrm{P}$ and $\mathrm{N}$ released per year $\left(\operatorname{Load}_{k g / \text { year }}\right)$ in the corresponding heights of tides that flood the mangrove forest (Fig. 3), were estimated at $85,137.50 \mathrm{~kg} /$ year of $\mathrm{P}$ and $304,062.50$ of $\mathrm{N}$ (Table 1). The time the charges of $\mathrm{P}$ and $\mathrm{N}$ released from sewage in the estuary would take to be 
Table 1 Estimated loads of $\mathrm{P}$ and $\mathrm{N}$ in sediments and in the trees of mangrove forest compared to the estimated loads $\mathrm{P}$ and $\mathrm{N}$ released from sewage in the Potengi estuary, with the corresponding time to reach the same quantities stocked

\begin{tabular}{lcccc}
\hline Stocks & Stocks in the sediments $(\mathrm{kg})$ & Stocks in the trees $(\mathrm{kg})$ & Estimated loads in sewages $(\mathrm{kg} /$ year) & Time to reach (year) \\
\hline $\mathrm{P}$ & 285,000 & 133,400 & $85,137.50$ & 4.9 \\
$\mathrm{~N}$ & $4,250,000$ & 197,800 & $304,062.50$ & 14.6 \\
\hline
\end{tabular}

equivalent to those stored in the sediments would be 4.9 years for $\mathrm{P}$ and 14.6 years for $\mathrm{N}$, equivalent to treatment time $(t)$ of the loads of $\mathrm{P}$ and $\mathrm{N}$ in years in a WTP with stabilization ponds (Table 1).

The fixed value of the services of the Potengi mangroves was estimated by the cost of deployment of the treatment system to an amount of US\$ 6,600,000.00. The construction costs $\left(C_{b}\right)$ were about US\$ 4,900,000.00, and the cost for treatment $\left(C_{t}\right)$ of $\mathrm{P}$ loads was US\$565,000.00 and $\mathrm{N}$ of US $\$ 1,700,000.00$ (Table 2), the latter being considered as cost of treatment, given that the handling of loads happens simultaneously in a WTP in about 15 year time.

The annual cost of the treatment given by the turnover rate $\left(T_{r}\right)$ or by the renewal rate in the stocks of the forest's trees was of US\$66,000.00/year for P and US\$ 11,300.00/ year for $\mathrm{N}$ charges (Table 2). This variation in values between the turnover rates $\left(T_{r}\right)$ of $\mathrm{P}$ and $\mathrm{N}$ is because the Potengi estuary mangrove accumulates about $47 \%$ of the $\mathrm{P}$ from the biotic compartment system (Ramos e Silva et al. 2007). As for the low values for the storage of $\mathrm{N}$, they are due to the accumulation about $5 \%$ of $\mathrm{N}$ from the system by the biota (Ramos e Silva et al. 2007).

Considering the mangrove area $\left(A_{m}\right)$ of 920 ha, the value of the service of holding the loads of $\mathrm{N}$ and $\mathrm{P}$ which are stored in the mangrove ecosystem $\left(V_{\$}\right)$ was about US\$ 7,200.00 / ha, and for the service of renewal rate of the loads $\mathrm{P}$ and $\mathrm{N}\left(V_{a \$}\right)$ was about US\$ 72.00/ha/year.

The low value of the turnover rate service, $1 \%$ in relation to services of retention in the sediments and in the trees, can be explained by the biomass production that is lost from the trees as litter, and this may or may not be retained within the forest, depending on the degree of tidal flow and the detritivorous activity of crabs. Concerning the Potengi mangrove wetlands, this assumption becomes a good aspect since only $10 \%$ of the litter is exported as leaf litter (macrolitter), and that this one leaves the forest nutrient-poor (Ramos e Silva et al. 2007).

Furthermore the turnover rate service means that every 12 years for $\mathrm{P}$, and every 7 years for $\mathrm{N}$, their respective stocks in the trees are renewed (Ramos e Silva et al. 2007), equivalent over those periods to a cost of treatment $\left(C_{t}\right)$ considerable by the renewal of stocks of of US\$ 792,700.00 for P and US\$78,800.00 for N. According to Ramos e Silva et al. (2007) the turnover rate is influenced by the biomass of trees, litter fall, and the concentrations of nutrients in the leaves and in the sediment.

It should still be considered the importance of mangroves in the import of organic and inorganic $\mathrm{P}$ and $\mathrm{N}$ being reported by several authors (Nedwell 1975; Boto 1992; Ramos e Silva et al. 2007), which closely resembles the processes of removal of $\mathrm{P}$ in a WTP where they preliminary recept phosphorus compounds in soluble form. For this reason, in sewage treatment stations, it becomes very difficult to remove it by decantation. Thus, as in mangroves, the chemical precipitation has proven to be more efficient in removing phosphates, being immobilized or adsorbed in the form of flocks by the use of aluminum and iron coagulants, besides the lime (Hammer 1979). However, studies have shown a greater need for aluminum sulfate to precipitate the phosphorus from sewage in the treatment plants, a ratio of 16:1 on average (Hammer 1979).

The removal of about 20 to $30 \%$ of phosphate and inorganic nitrogen by algae synthesis in the secondary biological treatment can be achieved. However, the cultivation

Table 2 Valuation of loads stored in the mangrove forest's compartments

\begin{tabular}{|c|c|c|c|c|c|c|c|}
\hline Stocks & Sediments (kg) & Trees (kg) & $\begin{array}{l}\text { Turnover rate } \\
\text { (kg/year) }\end{array}$ & $\begin{array}{l}\text { Construction } \\
\text { cost (US\$) }\end{array}$ & $\begin{array}{l}\text { Treatment } \\
\text { cost (US\$) }\end{array}$ & $\begin{array}{l}\text { Retention total } \\
\text { cost (US\$) }\end{array}$ & $\begin{array}{l}\text { Renewal cost } \\
\text { (US\$/year) }\end{array}$ \\
\hline $\mathrm{P}$ & 285,000 & 133,400 & 16,300 & $4,900,000.00^{(\mathrm{a})}$ & $565,000.00$ & $5,465,000.00$ & $66,000.00$ \\
\hline $\mathrm{N}$ & $4,250,000$ & 197,800 & 29,600 & $4,900,000.00^{(a)}$ & $1,700,000.00$ & $6,600,000.00$ & $11,300.00$ \\
\hline Heavy Metals & $31,443,000$ & 47,400 & 6,800 & $490,000.00^{(\mathrm{b})}$ & $12,600,000.00$ & $13,090,000.00$ & 800.00 \\
\hline
\end{tabular}

\footnotetext{
${ }^{a}$ The construction costs of WTP with stabilization ponds is the same for treatment loads of P and N, for they are treated simultaneously, considering a total retention value of US\$6,600,000.00 for the loads of $\mathrm{N}$ and $\mathrm{P}$ altogether

${ }^{\mathrm{b}}$ The costs with facilities or constructions of Zeolitic Plants are de $10 \%$ compared to WTP stabilization ponds, for treating an industrial wastewater flow of $10 \%$ for domestic sewage
} 
of algae has not proved to be effective and practical. Biological problems in the suitable balance of the ratio of Carbon: Nitrogen: Phosphorus, the intensity of sunlight, own $\mathrm{pH}$ and temperature control, as well as physical limitations of the large area required for an adequate retention period, and even a costly mechanical equipment to remove algae. With this, the process of photosynthesis for removal purposes has been avoided (Hammer 1979).

Otherwise, the lack of models regarding the hydrodynamics of the Potengi estuary prevented us from having or even simulating precise numbers corresponding to the amount of pollution loads that reach the mangrove wetlands, making it possible to infer the quantities of $\mathrm{N}$ and $\mathrm{P}$ available to mangroves. This is due to tidal influence in the availability of the nutrients $\mathrm{N}$ and $\mathrm{P}$ to mangrove forest, and the dilution of the charges according to the height of tide.

The concentrations of stable metals in the mangrove forest in trees $\left(E_{b}\right)$ and sediments $\left(E_{s}\right)$ was estimated in $31,490,500 \mathrm{~kg}$. The costs of removal of heavy metals $\left(C_{t}\right)$ by filters of zeolites were estimated at US\$12,600,000.00. Construction costs $\left(C_{b}\right)$ for the zeolite plant corresponded to US\$ 490,000.00. The service of retention of heavy metals $\left(V_{\$ h m}\right)$ by mangrove ecosystem of the estuary Potengi was estimated at US\$13,090,000.00 (Table 2).

Unlike the costs of treatment to remove $\mathrm{N}$ and $\mathrm{P}$, despite smaller stocks of heavy metals in the biota, the cost of retention of the heavy metal loads service in the sediments is proportionately much larger in relation to the service of retention of $\mathrm{P}$ and $\mathrm{N}$ loads (Table 2). Otherwise, comparing the costs for the renewal of the stocks of metals in the biota $\left(T_{r}\right)$, averaging $1 \%$ of the total stock of the ecosystem, they make it become negligible the costs for the renewal of stocks in the mangrove forest, since the deciduous tissues (leaves) have the lowest concentrations of $4 \%$ compared to the biota, making the renewal service equivalent to about US\$ 800.00/year, or on average less than US\$ $1.00 / \mathrm{ha} /$ year.

In this respect, the role of metal retention by the mangrove estuary has a preponderant ecological and economic factor, as industrial effluent treatment plants, representing about US\$ 14,200.00/ha, or twice as that for the removal of $\mathrm{P}$ and $\mathrm{N}$ loads.

Recreation and tourism in the area of mangroves are not very significant, although there has been interest in exploring the scenery offered by this environment (Grasso et al. 1997) currently. It appears that in the Potengi estuary this potential also remains little explored (STTU / Natal 1999).

In the Potengi estuary were identified tourism services such as crossing the ferry and happy hour, regarded as services of indirect uses of impression and contemplation of the environment respectively. The ferry crossing the Potengi estuary by tourists is provided indirectly as "business card" to people who visit the "Dunes Circle", where the mangroves give the impression of "green tranquilizer" of the landscape, and wildlife foraging activity in the vicinity of mangroves. Services of tour boats with "bar on board", and "live music with local singers" structure, known as "happy hour" at Potengi's sunset, the mangroves serve as the backdrop for contemplation of nature. A monthly average of 700 people do the happy hour kind of ride on the Potengi, and a monthly average of 24,000 tourists make the journey by ferry at the Potengi estuary (STTU / Natal 1999; Capitania das Artes / Natal 1999).

The uses of the Potengi mangroves as tourist services of direct use for environmental education, recreation, and researches, occur constantly by students and tourists visiting aboard of the boat "Chama Mare" adapted to make visits along the Potengi estuary, with tour guides and teachers. An average of 1,400 students per month, at an average price of US\$ 1.00 per person make use of the mangroves as a resource for Environmental Education. Likewise, wildlife watchers, university students, explore the Potengi estuary and the mangrove wetland's resources for research. An average of 20 journeys in small boats per month are conducted by fishermen for studies of mangroves. Also, the recreational use for fishing and boating is frequently performed in the estuary Potengi.

Based on the cost of the trips in the Potengi estuary applied to the perimeter of the mangrove forest used for this purpose (Table 3), and based on the tracks made in the Potengi estuary (Fig. 4) showed that aggregate potential values reach about US\$ 2.50 per kilometer of mangrove forest used as a the scenario of direct and indirect uses tourism uses.

With a perimeter of $20 \mathrm{~km}$ of mangrove scenarios, the Potengi estuary offers a potential tourism use of about US\$ $3,500,000.00 /$ year. It is estimated that an average of 70,000 people per year, or $1 \%$ of the population visiting the city of Natal are tourists, and that somehow they make a tourist use of the Potengi estuary (STTU / Natal 1999; Capitania das Artes / Natal 1999).

Approximate values were found by other studies using techniques of interviews with tourists, inferring the subjec-

Table 3 Classes of use of tourism and top costs per perimeter of mangrove area viewed in each ride along the Potengi estuary

\begin{tabular}{llcc}
\hline Tourism & Use & $\begin{array}{l}\text { Scenario } \\
(\mathrm{km})\end{array}$ & $\begin{array}{l}\text { Value } \\
\text { (US\$/Ride) }\end{array}$ \\
\hline Indirect & Environment impression & 4.12 & 71.10 \\
& Contemplation & 5.82 & 8.91 \\
Direct & Environmental Education & 12.50 & 3.10 \\
& Recreational & 12.50 & 7.75 \\
& Surveys & 4.10 & 3.60 \\
& Total= & 39.04 & 94.47 \\
\hline
\end{tabular}


Fig. 4 GPS mapped routes of the mangrove tourist rides in the Potengi estuary. The perimeter used as scenario is the same color line of the routes. Background image from the Google Earth, available in http://earth. google.com/

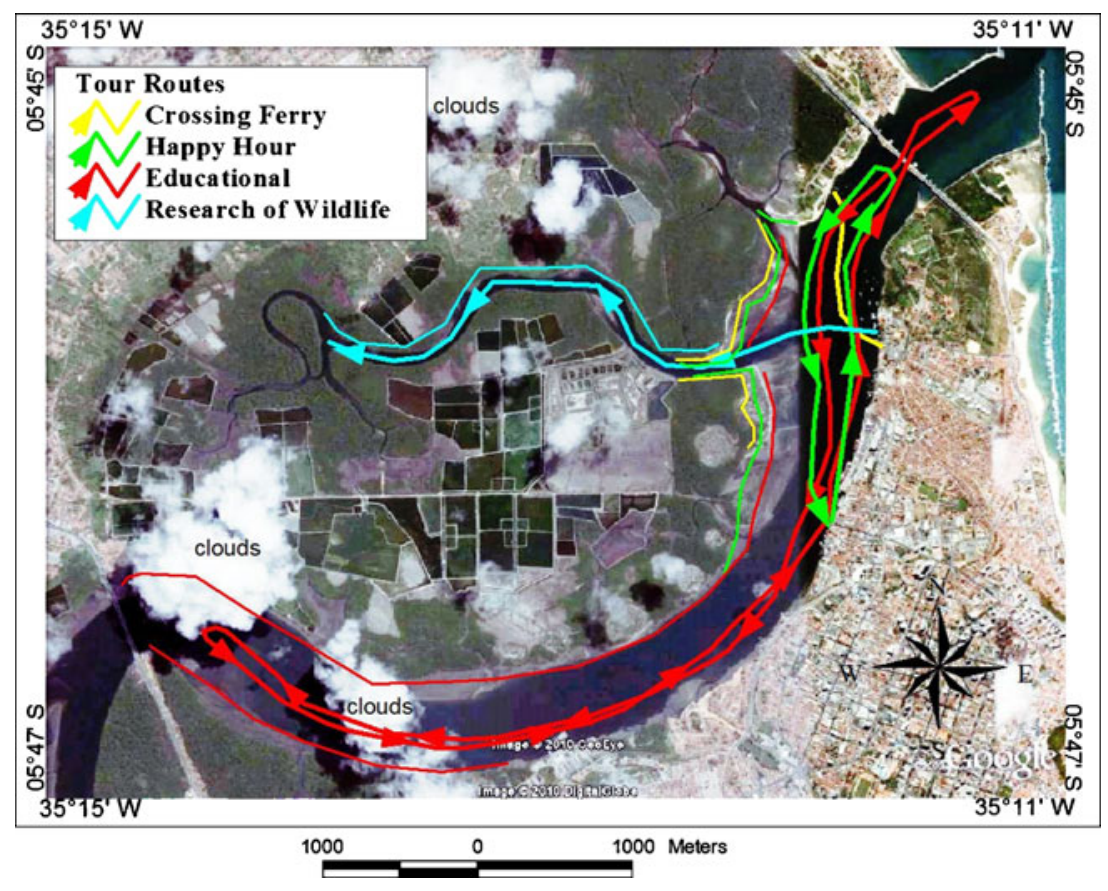

tive nature of value, as the case "by willing to pay", measuring the subjective value assigned to the goods and services of the ecosystem (Ramdial 1980; Grasso et al. 1997). The Cananéia / SP mangroves with nearly 10.000 ha of area, a potential value of US\$ 33,700,000 per year was estimated, with an emphasis on recreational fishing (Grasso et al. 1997), a relatively close value considering the area of the Potengi mangrove in 920 ha. RAMDIAL (1980) estimated a value of US\$ 8,000 / ha / year, including, besides the cost of travel, the visitors' recreational benefits of the Caroni River mangroves, in Trinidad Tobago, with an area of 5,000 ha. This work obtained in average US\$ $4,000.00$ / ha / year without considering the visitors's costs of travel.

The valuation of the potential use of aquaculture in the Potengi mangroves showed an area of 50 ha available in the
Fig. 5 Nautical Chart of the Port of Natal / RN integrated to the Environmental Sensitivity Chart, showing the contours of the depths 1-5 $\mathrm{m}$ (yellow dot line) available to the installations of cultivation modules. The segments of the land cover use are in color lines (e. g. mangroves areas bordered with green lines). Background image from the Google Earth, available in http://earth.google.com/

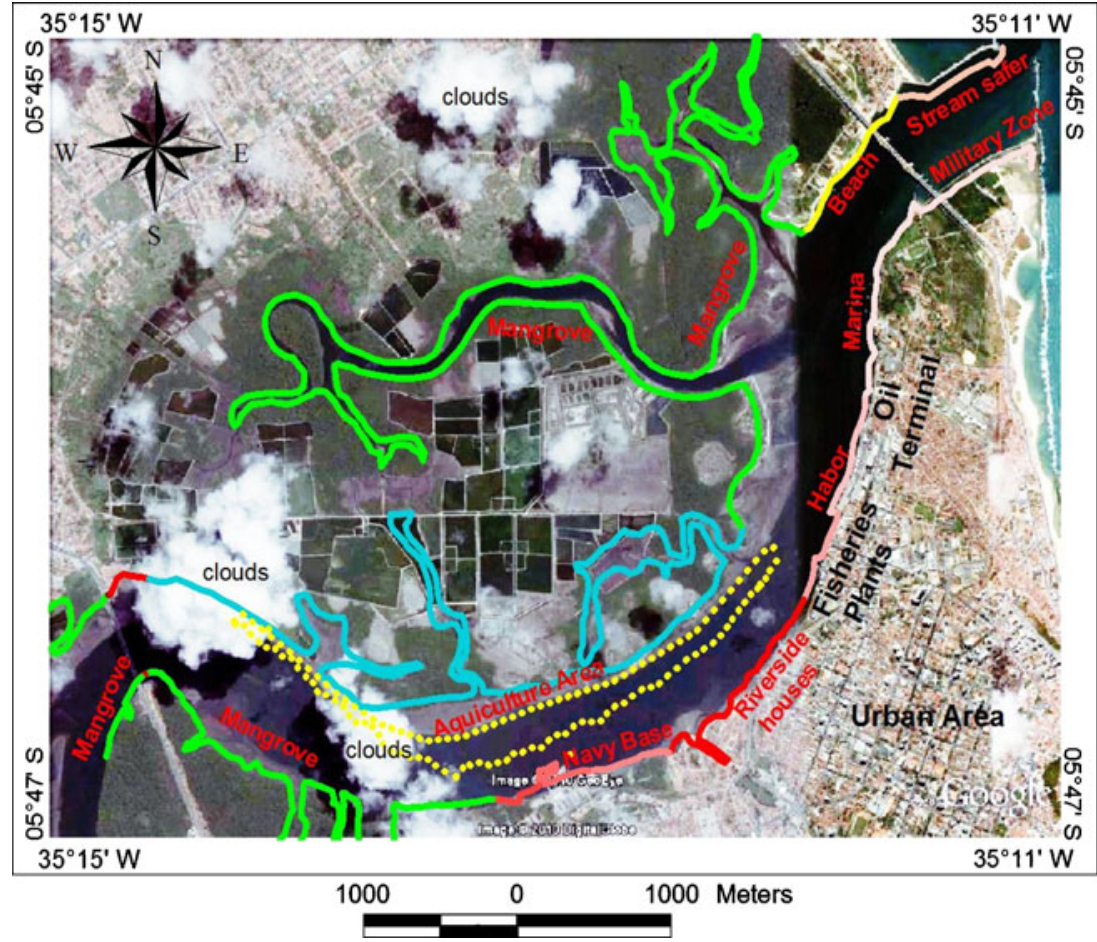


Table 4 Type of cultivation and its productivity with annual revenue and total income in cultivation area of 10 ha

${ }^{\text {a }}$ dry weight of the product

\begin{tabular}{lccc}
\hline Cultivated product & Productivity (t/ha/year) & Price (US\$/kg) & Rendimento total (US\$/ano) \\
\hline oysters & 18 & 7.69 & $1,384,200$ \\
mussels & 40 & 11.53 & $4,612,000$ \\
Algae & $12\left(^{\mathrm{a}}\right)$ & $0.27\left(^{\mathrm{a}}\right)$ & 32,400 \\
fish & 1.5 & 3.46 & 51,900 \\
shrimp & 25 & 7.69 & $1,922,500$ \\
& & total= & $8,003,000$ \\
\hline
\end{tabular}

Potengi estuary for the growth of oysters, mussels, algae, fish and shrimp by family cultivation (Fig. 5). If there were no sewage contamination, this would become a 274 ha area. Being divided into 5 (five) equal parts, you will get 10 ha for each of these types of crops. From this area the production and income for each type of cultivation, the costs were estimated related to the production values for fished food were converted to local market prices (Table 4).

The total crop had an estimated revenue de cerca de US\$ 8,000,000.00 / year without promoting the destruction of mangrove areas, which would be possible by the treatment of the estuarine waters of the Potengi mangroves wetlands. Dividing this aquaculture production total value by the mangrove forest area, the result was an income of US\$ 8,700 / ha / year. Such income could be even higher in case the the mangrove areas which have been destroyed by the salt processing plants, shrimp ponds and embankments for dwellings in the Potengy estuary were recovered, for this would increase the support of seeds and larvae supply for aquaculture, as well as would provide a higher supporting capacity by natural floods (IBAMA 1995), enhancing the quality and the quantity of the family cultivation areas.

In other mangrove areas values in exceeding US\$ $1,000,000.00$ / year were obtained by other authors accounting the production of fish in estuaries (D'Croz and Kwiecinski 1980; Primavera 1992; Diegues 1995; Primavera 1996).

Fig. 6 Example of spatial data model that was generated in the mangrove valuation in this work

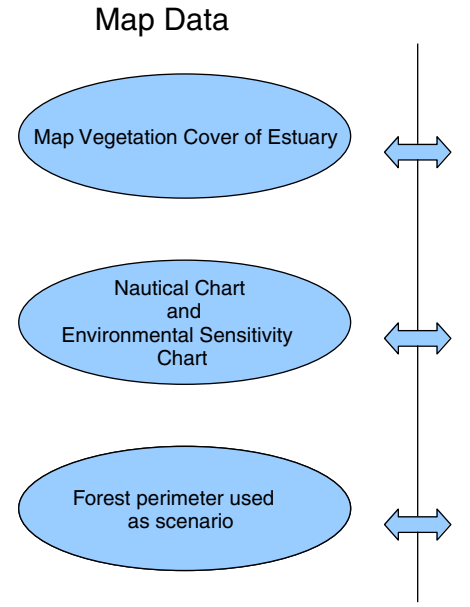

Spatial Database

\section{Conclusions}

The research of the natural-mean itself is done by compartmentalizing elements and species, often without a concern to understand the integral functioning of the ecosystem (Diegues 1995). This is due to the lack of models for quantification and valuation of essential functions (environmental services) that simulate the environmental conditions of ecosystems were verified in this work, bringing a major technical challenge for the valuation into light because of its conceptual and methodological approach.

Moreover this study demonstrated that a simple and effective methodology for integrating spatial data from various sources, allowing the quantification and spatialization of the data of ecological and economical nature, turning it possible to estimate the potential costs from cartographic scales based on maps, field data, and scientific papers, making up scenarios and patterns of use of mangrove areas like a flexible model (Fig. 6). It also allowed the combination of layers (over-layer) which made it possible to cross-check information about forests land, vegetation cover, biomass, trough volume of the estuary to the tidal level, mangrove wetlands perimeter observed as scenarios, by the manipulation of data in the digital means.

As for the environmental services evaluated in this work by the Potengi estuary mangrove wetlands, the biological filtration of the load of $\mathrm{P}, \mathrm{N}$ and heavy metals arising from
Paper/Report Data

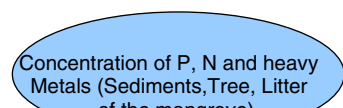

Metals (Sediments, Tree, Litter
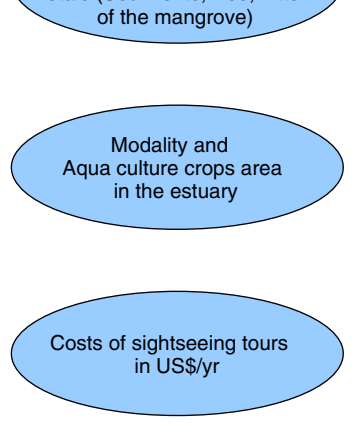

Attribute Database
Field Verification Data
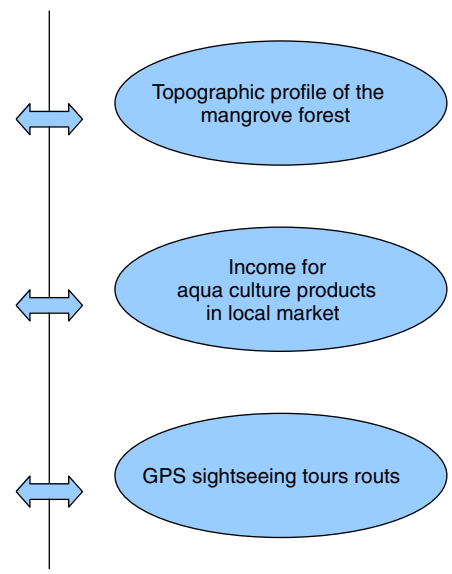

Complementary Database 
industrial and domestic effluents represent a fixed cost estimated in US\$ 5,300,000.00, due to construction and installation of a WTP with stabilization ponds and zeolitic plant, and US $\$ 14,300,000.00$ as cost of treatment representing a service of about US\$ $15,500.00$ / ha of mangrove. Yet, the annual costs for the valuation of the service of nutrient cycling (turnover rate) or time of renewal of $\mathrm{P}, \mathrm{N}$ and heavy metal stocks, of US\$66,800.00/year or US $\$ 72.00$ / ha / year, by the tourism activity and family aquaculture altogether, representing ecological services of about US\$11,500,000.00 / year, or income in the of US\$12,500.00 / ha / year, which means, every year it generates about $80 \%$ of the costs of retention of loads of $\mathrm{P}, \mathrm{N}$ and heavy metals.

This work achieved significant values of the ecological services performed by the Potengi estuary mangrove, highlighting the preservation of mangrove areas that are economically viable. Other goods and ecological services of the ecosystem have not been evaluated, for example: the importance of fishing activity in tropical areas and the marine environment near the coast, the protection from coastal erosion and the maintenance of the sediment balance, the habitat for fauna, including species of high commercial value, which depend on that environment as a place for feeding and reproduction, the protection and refuge for the young of migratory marine and oceanic species (mammals, fish, crustaceans).

Acknowledgements The first author thanks the scholarship granted by the Coordenação de Aperfeiçoamento de Pessoal de Nível Superior Coordination of Improvement of Higher Education Personnel (CAPES) through the Graduate Program in Aquatic Bioecology from the Universidade Federal do Rio Grande do Norte - Federal University of Rio Grande do Norte (UFRN).

Open Access This article is distributed under the terms of the Creative Commons Attribution Noncommercial License which permits any noncommercial use, distribution, and reproduction in any medium, provided the original author(s) and source are credited.

\section{References}

ABES (Associação Brasileira de Engenharia Sanitária) (1984) Custos de Construção de estações de tratamento. In: ABES, Revista de Engenharia Sanitária, ABES: v.23 n. 3, jul-set

Barbier EB (1989) The Economic Value of Ecosystems: 1-Tropical Wetlands. LEEC Gatepeker series GK 89-01. London Environmental Economics Centre, London, UK

Barbier EB, Koch WE, Silliman BR, Reed DJ, Perillo MEG, Hacker SD, Granek EF, Primavera JH, Muthiga N, Polasky S, Halpern BS, Kennedy CJ, Kappel CV, Wolanski E (2008) Coastal ecosystem-based management with nonlinear ecological functions and values. Sci Mag 319(5861):321-323

BIOMIN (1999) Toxicity and treatability of Gallium Arsenide Waste at receiving sewage treatment works. BIOMIN, Inc., USA

Boto KG (1992) Nutrients and Mangroves. In: Hawker DW (ed) Pollution in tropical aquactic system. CRC Press, Boca Raton, pp 130-145
CAERN (Companhia de Águas e Esgotos do Rio Grande do Norte) (1995) Plano Diretor de Esgotos Sanitários da Cidade do Natal-RN. Natal: Arco, p 394

Capitania das Artes / Natal (1999) Relatórios do Projeto Pôr-do Sol no Potengi (Departamento de Eventos): Prefeitura Municipal do Natal: Capitanias das Artes: Natal, p 55

ClarkLabs (1999) CartaLinx: the spatial data builder. Clark Labs Massachussets, USA

D’Croz L, Kwiecinski B (1980) Contribución de los manglares a las pesquerías de la Bahia de Panamá. Rev Biol Trop 28 (1): 13-29

DHN. Marinha do Brasil (Diretoria de Hidrografia e Navegação) (1973) Carta Naútica do Porto do Natal/RN: Capitania dos Portos (colour chart. Esc. 1:8.500)

DHN. Marinha do Brasil (Diretoria de Hidrografia e Navegação) (2004) Tábuas de Marés de 2001 a 2004 para o Porto de Natal/ RN. Rio de Janeiro, DHN, Marinha do Brasil

Diegues ACS (1995) Ecologia Humana e Planejamento em Áreas Costeiras. São Paulo: NUPAUB -USP

GARMIN (1998) International Inc. PC Software Kit for GPS 48. Leneka, KS (USA)

Grasso M, Tognella MMP, Schaeffer-Novelli Y (1997) Aplicação de Técnicas de Avaliação Econômica ao Ecossistema Manguezal. EDUSP, São Paulo

Hammer MJ (1979) Sistemas de Abastecimento de Água e Esgotos. Livros Técnicos e Científicos, Rio de Janeiro

IBAMA (Instituto Brasileiro do Meio Ambiente e Recursos Naturais Renováveis) (1995) Resumo da literatura sobre conceitos do uso de áreas de mangue, com especial referência para a aquicultura artesanal. Brasília -DF: IBAMA

IBGE (Instituto Brasileiro de Geografia e Estatística) (2000) Censos Demográficos (contagem de populações). IBGE, Rio de Janeiro

Imhoff K (1996) Manual de tratamento de águas residuárias. Ed. Edgard Blücher Ltda, São Paulo

Luzadis VA, Castello L, Choi J, Greenfield E, Kim SK, Munsell J, Nordman E, Franco C, Olowabi F (2010) The science of ecological economics: a content analysis of Ecological Economics, 1989-2004. Ann N Y Acad Sci 1185:1-10

MARPETRO (Petrobrás/Marpetro-Transporte Marítimo de Petróleo) (2002) Carta de Sensibilidade Ambiental à Derramamento de Óleo da Área de Influência do Porto do Natal/RN. (Colour Chart), esc.:1:10.000, Natal/RN .

Nedwell DB (1975) Inorganic nitrogen metabolism in a eutrophicated tropical mangrove estuary. Water Res 9:221-231

Primavera JH (1992) Intensive prawn farming in the Phillippines: ecological, social, and economic implications. AMBIO 20(1):28-33

Primavera JH (1996) Mangrove vs ponds. Aqua farm news, Tibauan, Iloilo, Philippines (ISSN 0116-6573) Jan-Feb

Ramdial B (1980) The social and economic importance of the Caroni mangrove swamps forests. Forestry Division, Trinidad and Tobago

Ramos e Silva CA (1996) Manguezal: ecossistema egoísta ou benevolente? Cienc Hoje 20(120):6-11

Ramos e Silva CA, Lacerda LD, Rezende CE (1990) Metals reservoir in a red mangrove forest. BIOTROPICA 22(4):339-345

Ramos e Silva CA, Lacerda LD, Silva LFF, Rezende CE (1991) Forest structure and biomass distribution in a red mangrove stand in Sepetiba Bay, Rio de Janeiro. Rev Bras Bot 14:21-25

Ramos e Silva CA, Rainbow PS, Smith BD (2001) Biomonitoring of trace metal contamination in the Potengi estuary, Natal (Brazil), using the oyster Crassostrea rhizophgohae, a local food source. Water Res 35(17):4072-4078

Ramos e Silva CA, Raimbow PS, Smith BD (2003) Biomonitoring of trace metal contamination in the mangrove-lined Brazilian coastal system using the oyster Crassostrea rhizophorae: comparative study of regions affected by oil, salt pond and shrimp farming activities. Hydrobiologia 501:199-206 
Ramos e Silva CA, Silva AP, Oliveira SR (2006) Concentration, stock and transport rate of heavy metals in a tropical red mangrove, Natal, Brazil. Mar Chem 99(2006):2-11

Ramos e Silva CA, Oliveira SR, Rêgo RDP, Mozeto AA (2007) Dynamics of phosphorus and nitrogen through litter fall and decomposition in a tropical mangrove forest. Mar Environ Res 64(2007):524-534

Robertson AI, Phillips MJ (1995) Mangrove as filters os shrimp pond effluent: predictions and biogeochemical research needs. Hydrobiologia 295:311-321

SEPLAN/RN. (Secretaria do Planejamento do Natal/RN) (1992) Perfil Ambiental do Estado do Rio Grande do Norte. Natal (RN): SEPLAN/RN

SEPLAN/RN. (Secretaria do Planejamento do Natal/RN) (1986) Caracterização e mapeamento dos manguezais do Rio Potengi. Natal (RN): SEPLAN/RN. p 67

Sperling MV (1996) Introdução à qualidade das águas e ao tratamento de esgotos. $2^{\mathrm{a}}$ ed. Belo Horizonte: Depto. Eng. Sanit e Amb. UFMG, p 243
Souza FES (1999) Estudo de Valoração das Áreas de Manguezal do Estuário Potengi/RN, Nordeste, Brasil. M.Sc. Thesis. Dissertação, Universidade Federal do Rio Grande do Norte, Natal, p 87

STTU/NATAL (Secretaria de Tráfego e Transporte Urbano do Natal/RN) (1999) Relatório de Serviço Aquaviário do Potengi. Dep de Operações e Permissões. Sec de Tráfego e Transporte do Mun. do Natal, Prefeitura Municipal do Natal: Natal/RN

UFRN (Universidade Federal do Rio Grande do Norte) (2004) Séries Climatológicas. Estação Climatológica, Depto. de Geografia UFRN (Universidade Federal do Rio Grande do Norte): Natal $(\mathrm{RN})$

Van Der Knaap WGM (1999) Research report: GIS - oriented analysis ot tourist time-space patterns to support sustanaible torurism development. Dep of Envir. Sciences, Land Use Planning Group, Wageningen Agricultural University, Nethelands. Tour Geogr 1 (1):56-69 